\title{
Christer Laurén, Johann Myking \& Heribert Picht 2008. Insikter om Insikt. Nordiska teser om fackkommunikation. Under medverkan av Sigurdur Jónsson. Oslo: Novus Forlag. 207 pages. ISBN 978-82-7099-475-5
}

The book under review ${ }^{1}$ has a prehistory of some importance for its evaluation, which I will therefore use as an introduction to my review. In 1997, the main authors of this book published another basic book called Terminologi som vetenskabsgren (Terminology as scientific discipline, Laurén et al. 1997), which was subsequently published in a German version (Terminologie unter der Lupe, Laurén et al. 1998). The aim of that book project was to present a Nordic view on the main questions of the terminological approach to the description of domain-specific language, and consequently the twelve chapters in the book treat topics like the development of terminology as a science, its basic elements, semiotic models of terminology, terminology in language planning, etc. To a large extent it was possible to read the 1997 book as an uninitiated scholar interested in the field of terminology and to end up having an overview of the Nordic positions in the development of terminological studies. The book could thus function as an introduction to terminology seen from the Nordic point of view.

The book was the result of regular meetings in Denmark funded by the Nordiska Kulturfonden. After the publication of the first book in its two language versions, the authors kept meeting on a regular basis, and the result of these subsequent meetings is the book under review. It is not explicitly presented as a sequel to the first book, but the first book is mentioned in the preface of the book under review, and the authors frequently refer to arguments set out in the first book when they argue for their positions in the new book. I will therefore start this review with some remarks about similarities and differences between the two books.

The organisation principle of the book under review is that each chapter is an argumentation spurred on by an initial thesis. The ten theses around which the book is organised are the following (in my translation):

1. Specialised communication is a cultural and semiotic phenomenon (18 pages)

2. Specialised communication is a legitimate field of interest of linguistics (5 pages)

3. Investigating specialised communication is to be seen as a part of linguistics (subdiscipline) (4 pages)

4. No absolute borders exist between specialised communication and other types of communication (22 pages)

5. Consequently, no absolute borders exist between terms and the rest of the lexicon, either (21 pages)

6. The relation between the knowledge of a domain (fagområde) and the forms representing this knowledge is arbitrary, but not necessarily unmotivated (11 pages)

7. Forms of representation varies with the needs of specialised communication (17 pages)

8. Conversion between forms of representation is always possible, but not always with a foreseeable result (8 pages)

1 As the book has already been reviewed in other venues (Humbley 2008; Simonnæs 2010), I will not give a detailed overview of the content of the book. Instead, I will concentrate upon some of the major implications of the book for the development of the field of studies into specialised communication. 
9. A domain has an inherent conceptual (dis)order, changing with the development of insights (erkendelsen) (9 pages)

10. Language use as well as the language system may be governed (styres) (55 pages)

As will be visible, the overall structuring of the book is like the one followed in the 1997 book, going from basic aspects of terminology as a discipline over discussions of the elements of terminology to its application in the field of actual communication. However, in the ordering of the new book according to a number of theses, I see a major difference between the first book and the book under review: Where the first book is intended to give a fairly global introduction to the authors' view on terminology, the idea behind this book seems to be to discuss basic issues inside the field of terminology and present the positions of the authors to these issues. The major difference lies in the intended audiences. I would think that the first book is intended for anyone with interest in the field of terminology (cf. the introduction, in which it is stated that the discipline of terminology is important for "moderna språkforskare och språkstuderende” (modern linguists and students of linguistics, Laurén et al. 1997: 11). On the other hand, the book under review seems to be more oriented towards readers already initiated into terminological studies. For one will have to be acquainted with the field in order to be able to see the relevance of discussions of theses like "Specialised communication is a legitimate field of interest of linguistics" or "Consequently, no absolute borders exist between terms and the rest of the lexicon, either". They are the consequence of an on-going development in the field of terminology to leave a (traditional?) position where terminology was presented as being oriented towards an object that was different from that of linguistics in order to integrate the field of terminology more into the (linguistic) study of specialised communication (cf. the part of the introduction cited above). This development has been visible in the emergence of approaches like (Temmerman 2000) and (Cabré 1999), but was also already visible in many of the discussions in the 1997 book by the authors (cf. for example pp. 204-215 on the relations between terms and concepts).

So the positions held in the book under review are neither surprising nor revolutionary in the broader picture of investigations into specialised communication. The general feeling one has after reading the book is that the authors through their discussions have reached some balanced and fairly non-controversial positions, at least for a reader from outside the field of terminological studies: they position terminological studies as a subdiscipline of linguistics (thesis 3 ), they discard of the absolute distinction between terms and other types of words (thesis 5), and they claim that it is possible to govern (styre) language use and language system, although such governing may not necessarily be successful (thesis 10). However, the theses and their elaboration in the ensuing chapters are definitely interesting in the development of the discipline and its cooperation with other disciplines interested in specialised communication as pointed statements showing a shift in the terminological mainstream and an opening towards other approaches.

Although I find all the theses and the ensuing argumentation interesting, I want to highlight two aspects presented in the book, viz. the aspect of forms of representing terminological content (theses 7 and 8 ) and relations to language planning (thesis 10). Here, I see the major new contributions from the book, as the ideas presented here are major developments of thoughts more briefly introduced earlier. The aspect of different forms of representation (verbal as well as non-verbal, theses 7 and 8) was treated already in the first book, but with emphasis upon verbal and semi-verbal representations. By semi-verbal I mean notational forms like music or mathematics. In the book under review a much fuller range of representational forms has been taken into consideration. Among the non-verbal forms, types like auditive, gustative and olfactive forms of representation are treated and their relations to differing needs of specialised communication are systematically discussed. Furthermore, the question of convertibility between different forms is discussed separately under thesis 8 . Loyal to the basic assumptions of terminology, the topic is treated from the point of view of systematicity and taxonomy, which may seem foreign to many researchers inter- 
ested in the aspect from the point of view of more semiotically oriented studies of multimodality. However, I see the major contribution in presentations like these in the fact that they are important steps towards enabling connections between studies in terminology and studies in multimodality, which play a growing role in the field of specialised communication.

The chapter following thesis 10 on the viability of language planning is by far the longest of the chapters in the book. It consists of two major parts: One is a longer description of the development of language planning attempts in Iceland and the different positions towards planning represented in this development. The subchapter was written by an invited author (Sigurdur Jónsson). It demonstrates that although especially a very strong group of intellectual participants failed in inducing the ideological positions they wanted to be dominant in the modern Icelandic culture through language planning, they managed to induce the idea that language planning is actually a viable and relevant task. In the same vein, the main authors of the book in the second part of the chapter present arguments for why language planning is definitely possible, relevant and necessary in order to counterbalance a position, according to which the faith of a language and its application in different domains is left to the market. Therefore they set up a conceptual system around the field of domain dynamics (including loss of domain as well as gain of domain as possibilities) in order to introduce relevant concepts in this connection in context. They see an important opposition between planning and leaving development to the market concerning the domain dynamics of a language, and they explain why the status of a language in this context is relevant. However, they also in this chapter present a balanced position which does not see language planning as necessarily implying very severe instruments like statutory regulations etc., as has been attempted, among other places, in France. They mainly argue for an awareness of the fact that in this field also (as in the general field of economy and society) marketization is not a sufficient instrument in order to reach optimal goals. As a consequence, they suggest a number of ways in which means of counterbalancing may be brought to bear, without stray-jacketing language users. In this connection, the idea that language planning is a sensible venture, but one where a successful outcome is not secured appears to me as an important insight.

By way of summing up my impression of the book, the argumentations in the different chapters are well ordered and easy and interesting to follow. One of the authors has been the main responsible for writing each chapter, and this is reflected in the language chosen for each chapter (written in Danish, Swedish or Norwegian). Furthermore, it is visible that some of the authors are more interested in laying down a neatly structured argument on the basis of preliminary definitions (reminiscing treatises of logic) than others, but the variation in the organisation of the different chapters is refreshing when reading a book with a level of abstraction as high as this one. The organisation according to theses which only to a limited degree depend on each other is somewhat detrimental to the coherence of the book across the chapters. However, this is probably the price to be paid for writing a book which wants to deal with a high number of well-delimited aspects of the theory in the same book, as these actually do not depend upon each other. Consequently, this point is a good example of why I would definitely recommend the book for readers with some initiation into the thinking of terminological studies, as it sums up very well the positions of some of the leading figures in the Scandinavian terminology and shows very well the line of development that they have been following over the last 20 years and thus gives us a front-end insight into the thinking of this group. However, for readers without prior experience with terminology, I would recommend that they read the 1997 book first.

\section{References}

Cabré, M. Teresa 1999: Terminology : theory, methods and applications. Amsterdam: Benjamins.

Humbley, John 2008: Review of: “Insikter om insikt.”. In LSP \& Professional Communication 8, 2, 123-128. 
Laurén, Christer/Myking, Johan/Picht, Heribert 1997: Terminologi som vetenskapsgren. Lund: Studentlitteratur. Laurén, Christer/Myking, Johan/Picht, Heribert 1998: Terminologie unter der Lupe. Wien: IITF.

Simonnæs, Ingrid 2010: Rezension von Laurén et al. (2008): Insikter om Insikt. Nordiska teser om fackkommunikation. In Fachsprache, 32, 3/4, 197-201.

Temmerman, Rita 2000: Towards new ways of terminology description. The sociocognitive approach. Amsterdam/ Philadelphia: John Benjamins.

Jan Engberg 